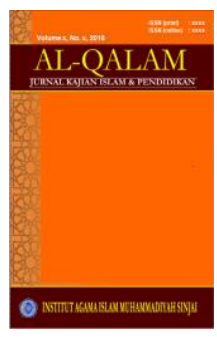

AL-QALAM

Jurnal Kajian Islam \& Pendidikan

Volume 06 No 012014

ISSN (print) : 1858-4152

ISSN (online) : -

Homepage : http://journal.iaimsinjai.ac.id/index.php/al-qalam

\title{
KAIDAH TAFSIR PADA MASA NABI DAN SAHABAT
}

\author{
Oleh: Amir Hamzah
}

\begin{abstract}
Abstrak
Kaidah tafsir dapat diartikan sebagai pedoman dasar yang digunakan secara umum guna mendapatkan pemahaman atas petunjuk-petunjuk al-Qur'an. Oleh karena penafsiran merupakan suatu aktivitas yang senantiasa berkembang, sesuai dengan perkembangan sosial, ilmu pengetahuan dan bahasa, kaidahkaidah penafsiran akan lebih tepat jika dilihat sebagai suatu prosedur kerja. Dengan pengertian ini, kaidah tersebut tidak mengikat kepada mufasir lain agar menggunakan prosedur kerja yang sama. Setiap mufasir berhak menggunakan prosedur yang berbeda asalkan memiliki kerangka metodologi yang dapat dipertanggungjawabkan.

Tafsir Nabi dan sahabat harus tetap dilibatkan dalam penafsiran ayat-ayat alQur'an, bahkan dijadikan sebagai salah satu sumber penafsiran. kalaupun terjadi perbedaan penafsiran ulama kontemporer atau cendekiawan Islam dengan tafsir Nabi dan sahabat maka hal itu tidak harus divonis salah atau menyimpang akan tetapi harus memperhatikan latar belakang, metodologi, subtansi, subjek dan objek yang berbeda sehingga tidak mudah saling menyalahkan dan saling mengklaim kebenaran.
\end{abstract}

Kata Kunci: Kaidah Tafsir, Pada Nabi dan sahabat

\section{PENDAHULUAN}

\section{A. Latar Belakang Masalah}

1-Qura'n al-karim adalah kitab samawi yang paling terakhir diturunkan A dan berfungsi sebagai petunjuk bukan hanya terhadap anggota masyarakat Arab akan tetapi juga bagi seluruh umat manusia hingga akhir zaman nanti. Al-Qur'an memuat seluruh aspek kehidupan manusia, baik aspek vertikal maupun horizontal bahkan hubungan dengan alam semestapun tertera dalam al-Qur'an. ${ }^{2}$

Prinsip, doktrin dan ajaran-ajaran yang disampaikan oleh al-Qur'an sangat global dan memungkinkan setiap generasi memberikan interpretasi yang berbeda dengan para cendikiawan sebelumnya karena al-Qur'an menggunakan bahasa

${ }^{1}$ Dosen Jurusan Ushuluddin STAIN Palopo

${ }^{2}$ Manna' al-Qat\}t\}a $>\mathrm{n}$, Maba $>$ his $\mid$ fi $>$ 'Ulu>m al-Qur'a $>n$ (Cet. XIX; Bairut: Muassah al-Risa>lah, 1406 H./1983 M.), h. 18. 


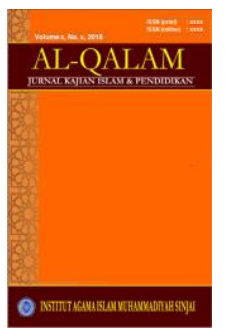

yang sangat tinggi sastranya dan mengandung berbagai rahasia yang tidak mungkin ditangkap secara sama oleh semua kalangan. ${ }^{3}$

Sebagai pembawa kalam ilahi, Rasulullah adalah orang pertama yang menjadi tumpuan untuk menjelaskan dan menafsirkan kalimat atau ayat al-Qur'an yang kurang jelas atau masih berlaku umum, sebab Nabi adalah penerima dan penyampai wahyu sebagaimana dalam QS. al-Nahll: 64.

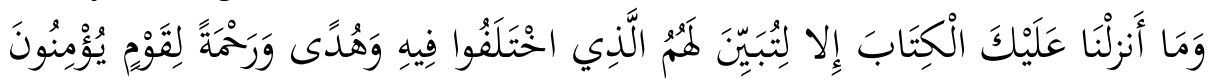

Artinya:"Dan kami tidak menurunkan kepadamu al-Kitab (al-Qur'an) ini, melainkan agar kamu dapat menjelaskan kepada mereka apa yang mereka perselisihkan itu dan menjadi petunjuk dan rahmat bagi kaum yang beriman." 4

Sahabat sebagai sasaran pertama al-Qur'an, jika tidak paham makna dan maksudnya akan segera bertanya kepada Rasulullah dan direspon langsung oleh Rasulullah saw., namun Rasulullah tidak menafsirkannya mengikuti alur fikirannya sendiri akan tetapi menurut wahyu ilahi. Penjelasan dan penafsiran Rasulullah hanyalah pelantara saja, sedang hakikatnya, Allahlah sebagai penafsir pertama. ${ }^{5}$ Dalam QS. al-Najm ayat 2-3, Allah swt. berfirman:

$$
\text { وَمَا يَنْطِقُ عَنِ الْوَى. إِنْ هُوَ إلالاحَحْيُ يُوحَى }
$$

Artinya: "Dan tiadalah yang diucapkannya itu (al-Quran) menurut kemauan hawa nafsunya. Ucapannya itu tiada lain hanyalah wahyu yang diwahyukan (kepadanya)." 6

Untuk mengetahui sejauh mana penafsiran Nabi dan sahabat, maka perlu adanya penelusuran sejarah tentang berbagai upaya ulama dalam mengembangkan kaidah-kaidah penafsiran dengan tujuan mengetahui prosedur kerja para ulama tafsir dalam menafsirkan al-Qur'an sehingga penafsiran tersebut dapat digunakan secara fungsional oleh masyarakat Islam dalam menghadapi berbagai persoalan kehidupan.

Kaidah-kaidah ini kemudian dapat digunakan sebagai referensi bagi pemikir Islam kontemporer untuk mengembangkan kaidah penafsiran yang sesuai dengan perkembangan zaman. Namun kaidah penafsiran tersebut tidak berperan

${ }^{3}$ Pada generasi awal (sahabat) tidak sama pemahaman dan pengetahuannya terhadap alQur'an, baik kuantitas maupun kualitasnya, apatahlagi generasi setelahnya. Lihat: Muhammad Husain al-Z|ahabi>, al-Tafsi>r wa al-Mufassiru>n, Juz. I (CD ROM al-Maktabah al-Sya>milah), h. 34 .

${ }^{4}$ Departemen Agama RI, al-Qur'an dan Terjemahnya, (Bandung: Syaamil Cipta Media, 1426 H./2005 M.), h. 273.

${ }^{5}$ Ahmad Asy-Syirbashi, Sejarah tafsir al-Qur'an (Jakarta: Pustaka Firdaus, 2001 M.), h.

${ }^{6}$ Departemen Agama, op.cit., h. 526. 


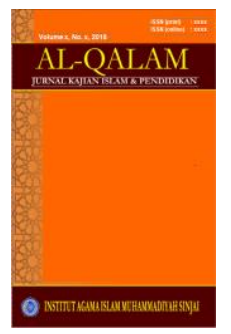

sebagai alat justifikasi benar-salah terhadap suatu penafsiran, akan tetapi kaidah tersebut lebih berfungsi sebagai pengawal metodologis agar tafsir yang dihasilkan bersifat obyektif dan ilmiah serta dapat dipertanggungjawabkan, sebab produk tafsir pada dasarnya adalah produk pemikiran manusia yang dibatasi oleh ruang dan waktu.

\section{B. Rumusan Masalah}

Sebagaimana pemaparan-pemaparan yang tertuang dalam latar belakang masalah, dapat dibuat beberapa poin untuk dijadikan sebagai rumusan masalah dalam makalah ini sebagai berikut:

1. Apa yang dimaksud dengan kaidah tafsir?

2. Apa saja bentuk kaidah tafsir Nabi dan bagaimana pengaplikasiannya?

3. Bagaimana bentuk kaidah tafsir sahabat dan cara pengaplikasiannya?

\section{PEMBAHASAN}

\section{A. Pengertian Kaidah Tafsir}

Kaidah tafsir berasal dari bahasa Arab yaitu قاعدة dan التفسير. Qa> 'idah yang akar katanya terdiri dari huruf 2 memiliki arti duduk sebagaimana dalam surah $a l-N u>r: 60$ :

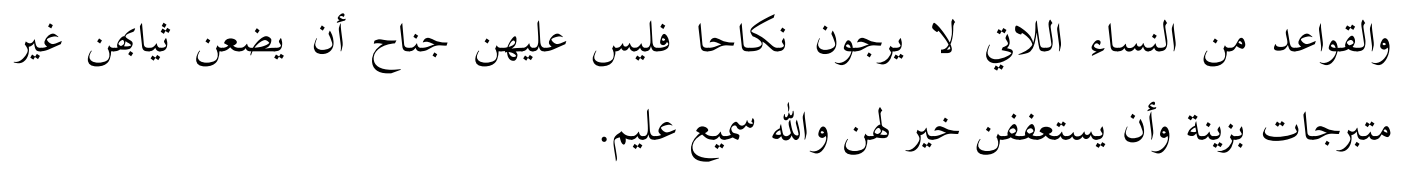

Artinya: "Dan perempuan-perempuan tua yang telah terhenti (dari haid dan mengandung) yang tiada ingin kawin (lagi), tiadalah atas mereka dosa menanggalkan pakaian mereka dengan tidak (bermaksud) menampakkan perhiasan, dan berlaku sopan adalah lebih baik bagi mereka. dan Allah maha mendengar lagi maha bijaksana."7

Menurut Fakhr al-Di>n al-Ra>zi>, yang dimaksud al-qawa > 'id dalam ayat tersebut adalah perempuan-perumpuan yang duduk dan berdiam lama serta tetap pada satu kondisi. Oleh karena itu, zaman bisa disebut maq'ad akan tetapi tidak bisa disebut al-majlis. ${ }^{8}$ Sehingga secara etimologi, kaidah adalah sesuatu yang ditetapi oleh perkara tertentu atau sesuatu yang menjadi dasar perkara lain.

Kata $a l$-qawa $>$ 'id juga bermakna pondasi atau dasar sebagaimana dalam surah al-Baqarah: 127:

${ }^{7}$ Departemen Agama, op.cit., h. 358.

${ }^{8}$ Abu Abdillah Muhammad ibn Umar Fakhruddin al-Ra>zi>, Mafa>tih\} al-Gaib, Juz. XV (Bairut: Da>r al-Fikr, 1414 H./1992 M.), h. 46. 

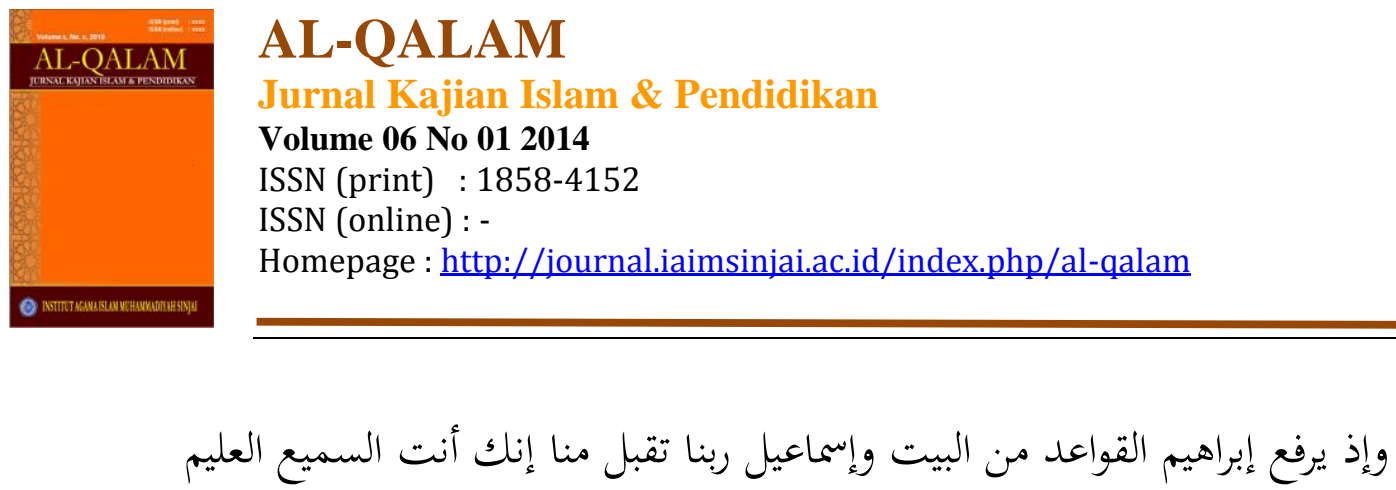

Artinya: "Dan (ingatlah), ketika Ibrahim meninggikan (membina) dasardasar baitullah bersama Ismail (seraya berdoa): "Ya Tuhan kami terimalah daripada kami (amalan kami), sesungguhnya Engkaulah yang maha mendengar lagi maha mengetahui".

Kedua makna tersebut dapat disatukan bahwa yang dimaksud dengan alqawa $>$ 'id adalah sesuatu yang menjadi asal atau dasar yang menjadi pijakan perkara lain.

Sedangkan secara termenologi, ulama memberikan beberapa definisi yang beragam redaksinya, meskipun subtansinya sama, antara lain:

- Menurut al-Jurja>ni>, al-qa>'idah adalah masalah umum yang mencakup seluruh bagian-bagiannya. ${ }^{10}$

- Menurut Ah\}mad Muh\{ammad al-Sya $>\mathrm{f}^{\prime} \mathrm{i}>$ yang dikutip oleh Muchlis Usman, al-qa $>$ 'idah adalah hukum-hukum yang bersifat universal yang hukum juz'i (partikal) yang banyak masuk di bawah hukum tersebut. ${ }^{11}$

- Menurut Ah\}mad al-Fayu>mi>, al-qa>'idah adalah perkara umum yang mencakup seluruh bagian-bagiannya. ${ }^{12}$

Dari beberapa definisi di atas, dapat disebutkan bahwa al-qa> 'idah adalah hukum atau kaidah universal yang membawahi beberapa hukum atau kaidah partikal.

Sedangkan kata al-tafsi $>r$ yang terdiri dari menjelaskan sesuatu dan menjadikannya terang benderang, ${ }^{13}$ sebagaimana dalam surah al-Furqa $>n: 33$.

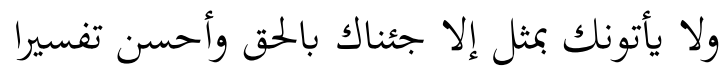

Artinya: "Tidaklah orang-orang kafir itu datang kepadamu (membawa) sesuatu yang ganjil, melainkan kami datangkan kepadamu suatu yang benar dan yang paling baik penjelasannya." 14

${ }^{9}$ Departemen Agama, op.cit. h. 20.

${ }^{10}$ 'Ali> ibn Muh\{ammad ibn 'Ali> al-Jurja>ni>, al-Ta'ri>fa>t (Cet. I; Bairut: Da>r alKita>b al-'Arabi>, 1405 H.), h. 219.

${ }^{11}$ H. Muchlis Usman, Kaidah-kaidah Ushuliyah dan Fiqhiyah (Cet. IV; Jakarta: Raja Grafindo Persada, 2002 M.), h. 3.

${ }^{12} \mathrm{Ah}\{\operatorname{mad} \mathrm{ibn} \operatorname{Muh}\{\operatorname{ammad} \mathrm{ibn}$ 'Ali> al-Fayu>mi>, al-Mis $\} b a>h\}$ al-Muni $>r$ fi $>$ Gari $>b$ al-Syarh\} al-Kabi>r li al-Ra>fi' $i>$, Juz. II (Bairut: al-Maktabah al-'Ilmiyah, t.th.), h. 510.

${ }^{13} \mathrm{Abu}>$ al-H $\{$ usain Ah\}mad ibn Fa>ris ibn Zakariya>, Maqa>yi>s al-Lugah, Juz. IV (Bairut: Ittih\}a>d al-Kita>b al-'Arabi>, 1423 H./2002 M.), h. 402.

${ }^{14}$ Departemen Agama, op.cit., h. 363. 


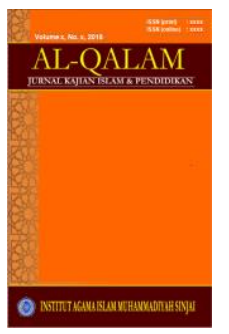

Menurut Ibnu 'A $<$ syu $>$ r, kata tafsi $>r$ dalam ayat ini bermakna penjelasan dan perincian tentang makna sesuatu, khususnya yang terkait denga argumentasi dan dalil. ${ }^{15}$

Secara termenologi, ulama juga memberikan beberapa definisi yang satu sama lain berbeda redaksinya meskipun kandungan dan cakupannya sama, yaitu:

- Menurut Mus\}t\}afa> Muslim, al-tafsi>r adalah ilmu yang dapat mengungkap makna-makna ayat-ayat al-Qur'an dan menjelaskan maksud Allah dalam ayat tersebut sesuai dengan kemampaun individu manusia. ${ }^{16}$

- Menurut al-Zarqa>ni>, al-tafsir adalah ilmu yang membahas tentang alQur'an dari segi dila>lah (petunjuk)-nya terhadap maksud dan kehendak Allah sesuai dengan kemampuan manusia. ${ }^{17}$

- Menurut al-Zarkasyi>, al-tafsir adalah ilmu yang dapat digunakan mengetahui pemahaman al-Qur'an yang diturunkan kepada Rasulullah saw., menjelaskan makna-maknanya dan mengeluarkan hukum-hukum dan hikmah-hikmah yang terkandung di dalamnya dengan bantuan ilmu linguistik, nahwu, tas\}ri>f, ilmu al-baya $>n, u s\} u>l$ al-figh, qira $>a h$, asba $>b$ al-nuzu>l dan $n a>$ sikh-mansu $>k h .^{18}$

- Menurut al-Alu>si, ilmu yang membahas tentang tata cara pengucapan lafaz-lafaz al-Qur'an, madlu>l (indikasi), hukum-hukum tunggal atau tarki $>b$ (prase), dan makna-makna yang terkandung dalam susunan kalimat al-Qur'an serta ilmu-ilmu pelengkapnya. ${ }^{19}$

Dari definisi-definisi ulama di atas, dapat disimpulkan bahwa al-tafsi $>r$ adalah ilmu yang membahas tentang maksud dan tujuan Allah swt. dalam alQur'an sesuai dengan kemampaun manusia dengan menggunakan semua ilmu yang dibutuhkan dalam mengungkap dan memahami makna-makna ayatnya.

Berdasarkan pengertian $a l-q a>$ 'idah dan $a l$-tafsi $>r$ yang telah dipaparkan di atas, maka yang dimaksud dengan kaidah tafsir adalah hukum-hukum universal yang digunakan untuk sampai pada pengkajian makna-makna al-Qur'an dan mengetahui tata cara mendapatkan faedah-faedahnya. jadi kaidah tafsir

${ }^{15}$ Muh\{ammad al-T $\{\mathrm{a}>$ hir ibn $\operatorname{Muh}\{\operatorname{ammad}$ ibn Muh\{ammad al-T $\{\mathrm{a}>$ hir ibn 'A $<$ syu $>$ r al-Tu>nisi>, al-Tahri $>$ r wa al-Tanwi $>r$, Juz. 19 (Tu>nis: al-Da>r al-Tu>nisiyah li al-Nasyr, 1984 H.), h. 23 .

${ }^{16}$ Mus $\}$ t $\}$ afa $>$ Muslim, Maba $>h\{i s \mid$ fi $>$ al-Tafsi $>r$ al-Maud $>u>' i>$ (Cet.I; Damsyiq: Da>r al-Qalam, 1410 H./1989 M>), h. 15.

${ }^{17}$ Muh $\{$ ammad Abd al-'Az $\} \mathrm{i}>\mathrm{m}$ al-Zarqa>ni>, Mana>hil al-'Irfa $>n$ fi $>$ 'Ulu>m alQur'a>n, Juz. I (Cet. I; Bairut: Da>r al-Fikr, 1996 M.), h. 4.

${ }^{18} \mathrm{Abu}>$ 'Abdillah Muh\{ammad ibn Baha>dir al-Zarkasyi>, al-Burha>n fi> 'Ulu>m alQur'a>n, Juz. I (Bairut: Da>r al-Ma'rifah, $1391 \mathrm{H}>$ ), h. 13.

${ }^{19} \mathrm{Abu}>$ al-Fad $>1 \mathrm{Mah}\{\mathrm{mu}>\mathrm{d}$ al-Alu $>\mathrm{si}>, R u>h\{$ al-Ma'a $>n i>f i$. Tafsi $>r$ al-Qur'a $>n$ al$' A z\} i>m$ wa al-Sab'i al-Mas $\mid a>n i>$, Juz. I (Bairut: Da>r Ih\}ya> al-Tura>s| al-'Arabi>, t.th.), h. 4. 


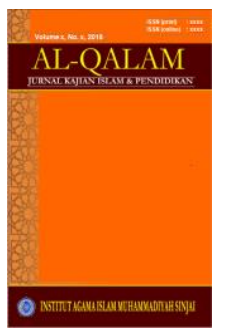

merupakan asas atau dasar utama yang dibutuhkan oleh para mufassir dalam memahami al-Qur'an.

Yang dimaksud tafsir Nabi adalah penafsiran yang dilakukan oleh Rasulullah saw. dengan jelas. Penafsiran Nabi tersebut bisa dilakukan dengan dua cara, yaitu:

- Langsung disampaikan oleh Nabi tanpa didahului pertanyaan atau permintaan.

- Disampaikan oleh Nabi setelah ada pertanyaan dan atau permintaan dari para sahabat. $^{20}$

Sedangkan penafsiran para ulama tafsir dengan menggunakan hadis atau sunnah tidak dapat dikategorikan tafsir Nabi akan tetapi disebut al-tafsi $>r$ bi alsunnah.

Sementara tafsir sahabat adalah penafsiran yang dilakukan oleh para sahabat Nabi terhadap ayat-ayat al-Qur'an.

\section{B. Bentuk-bentuk Kaidah Tafsir Nabi dan Aplikasinya}

Rasulullah saw. adalah penafsir pertama terhadap al-Qur'an dan pemberi penjelas terhadap al-Qur'an. ${ }^{21}$ Penafsiran dan penjelasan Rasulullah terhadap alQur'an beraneka ragam dan bertingkat-tingkat. Ada yang berfungsi sebagai baya $>n$ al-ta'ki>d (memperkuat dan menggarisbawahi kembali isi al-Qur'an) dan ada yang bersifat baya>n al-tafsi>r (memperjelas, merinci dan membatasi pengertiannya). ${ }^{22}$

Disamping itu, Rasulullah saw. dibekali dengan wahyu dan diberikan garansi ma's\}um terhadap penafsirannya, sehingga tafsirnya memiliki keistimewaan yang tidak dimiliki penafsir lain dan sudah pasti kebenarannya. oleh karena itu, tafsir Nabi didahulukan dari yang lain.

Oleh karena bahasa al-Qur'an tidak selalu mudah difahami oleh kaum muslimin, Rasulullah saw. sebagai pembawa risalah berusaha mempermudah pemahaman firman-firman Allah tersebut melalui tafsir-tafsirnya. Penafsiran Nabi inilah yang dianggap ide ketuhanan yang disampaikan secara utuh dan tidak menyimpang.

Berikut adalah kaidah-kaidah yang terkait dengan tafsir Nabi saw. yang memposisikan tafsirnya pada posisi tertinggi:

${ }^{20}$ Musa $>$ 'id ibn Sulaima $>n$ ibn $\left.\mathrm{Na}>\mathrm{s}\right\}$ ir al-T\{ayya>r, al-Tafsi $>r$ al-Lugawi $l i$ alQur'a $>n$ al-Kari>m (Cet.I; al-Riya $>$ d $\{$ : Da>r Ibn al-Jauzi>, 1422 H.), h. 64.

${ }^{21}$ Muh $\{$ ammad Isma'i $>1$ Ibra $>$ him, al-Qur'a $>n$ wa I'ja $>z u h$ al-'Ilmi $>$ (Bairut: Da>r alS|aqa $>$ fah al-'Arabiyah, t.th.), h. 35.

${ }^{22}$ M. Quraish Shihab, Tafsir al-Mishbah, Juz. VII (Jakarta: Lentera Hati, 2005 ), h. 238. 


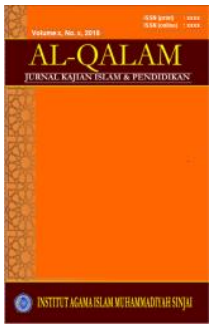

\section{Kaidah Pertama}

$$
\text { إذا عرف التفسير من جهة النبي صلى الله عليه وسلم فلا حاجة إلى قول من بعده }
$$

Artinya: "Jika ada penafsiran Nabi saw., maka penafsiran lain setelahnya tidak dibutuhkan lagi.

Dalam bahasa lain, penjelasan dan penafsiran Nabi terhadap lafazlafaz al-Qur'an didahulukan dari penjelasan apapun.

Di antara cara atau metode yang digunakan Rasulullah saw. dalam menafsirkan al-Qur'an adalah:

\section{a. Tafsir Nabi dengan Menggunakan Ayat al-Qur'an}

Rasulullah saw. seringkali menafsirkan al-Qur'an dengan menggunakan ayat-ayat al-Qur'an yang lain. Salah satu contohnya adalah ketika ayat الذين آمنوا ولم يلبسوا إيماهم بظلم (al-An’a>m: 82) para sahabat bertanya "Wahai Rasulullah saw. kalau demikian artinya, lalu siapa di antara kami yang tidak berbuat zalim?.

Kemudian Rasulullah saw. menjelaskan maksud dari kata z) ulm tersebut dengan menggunakan ayat lain, padahal sahabat berusaha menafsirkannya dengan pendekatan bahasa. Namun Rasulullah saw. menegur sahabat dengan mengatakan bahwa makna zalim tidak seperti yang dimaksud, akan tetapi zalim dalam ayat ini adalah kesyirikan, ${ }^{23}$ dengan membaca QS. Luqma>n: 13 . لا بني لا تشرك بالله إن الشرك لظلم عظيم

\section{b. Tafsir Nabi dengan Pendekatan Bahasa}

Di antara contoh penafsiran Nabi saw. dengan menggunakan pendekatan bahasa, yaitu pada saat menceritakan tanya jawab Allah swt. terhadap Nabi Musa dan kaumnya tentang tabli>g al-risa>lah, kemudian Nabi membaca ayat:

$$
\text { وكذلك جعلناكم أمة وسطا لتكونوا شهداء على الناس }
$$

lalu Nabi menafsirkan lafaz وسطا dengan di mana makna etimologi dari lafaz gadalah adil dan setengah. ${ }^{25}$

\section{c. Tafsir Nabi dengan Penjelasan Mura>diyah}

${ }^{23} \mathrm{Abu}>$ 'Abdillah Muhammad ibn Isma>'il al-Bukha>ri>, al-Ja>mi' al-S\}ah\{i>h li alBukha>ri>, Juz. VI (Cet. III; Bairut: Da>r Ibnu Kas|i>r, 1407 H./1987 M.), h. 2542.

${ }^{24}$ Ibid. Juz. II, h. 1215.

${ }^{25}$ Ibnu Fa>ris, Maqa >yis al-Lugah, op.cit. Juz. VI h. 82. 


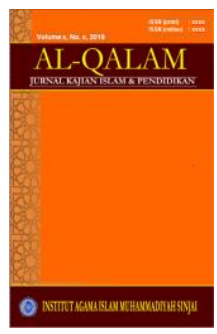

Tafsir Nabi dengan cara penjelasan mura>diyah merupakan tafsir yang paling banyak dilakukan oleh Rasulullah saw., baik penafsiran Nabi tersebut dengan cara menafsirkan terlebih dahulu kemudian membaca ayat yang ditafsirkan, atau membaca ayatnya terlebih dahulu kemudian menafsirkannya, ataukah penafsiran Nabi didahului sengketa atau kesalahpahaman sahabat terhadap ayat, ataukah Nabi bertanya tentang maksud ayat kepada sahabat, akan tetapi mereka tidak menjawabnya atau keliru memahaminya. ${ }^{26}$

Adapun contoh ayat yang ditafsirkan terlebih dahulu sebelum ayatnya atau istilah lain تقديم التفسير على المفسرة yaitu pada saat Nabi menjelaskan tentang orang miskin dengan mengatakan:

ليس المسكين الذي ترده التمرة والتمرتان ولا اللقمة ولا اللقمتان إنما المسكين الذي يتعفف.

Artinya: "Bukanlah orang miskin yaitu orang yang meminta-minta satu biji kurma atau dua dan atau satu suapan atau dua, akan tetapi orang miskin yang sebenarnya adalah orang yang tidak mau meminta-minta." Kemudian Nabi menyuruh membaca ayat yang terkait dengan penafsirannya:

$$
\text { واقرؤوا إن شئتم يعني قوله "لا يسألون الناس إلحافاك،rكan }
$$

Sebaliknya, terkadang Nabi menafsirkan ayat al-Qur'an dengan membacakan ayatnya terlebih dahulu, seperti ayat 6 dari surah alMut\}affifi>n:

$$
\text { يوم يقوم الناس لرب العالمين. }
$$

dengan mengatakan:

$$
\text { حتى يغيب أحدهم في رشحه إلى أنصاف أذنيه }
$$

Contoh penafsiran Nabi yang didahului oleh sengketa/perbedaan pendapat di kalangan sahabat yaitu pada saat salah seorang dari Bani Khadrah dan Bani 'Amr ibn 'Auf berbeda pendapat tentang mesjid yang dimaksud dalam ayat لمسجدد أسس على التقوى, apakah mesjid

${ }^{26} \mathrm{Kha}>\operatorname{lid}$ ibn 'Us $\mid \mathrm{ma}>\mathrm{n}$ al-Sabt, Qawa $>$ 'id al-Tafsi $>r$, Jam'an wa Dira $>$ sah, Juz. I (Cet. I; al-Mamlakah al-'Arabiyah al-Sa'u>diyah, Da>r ibn 'Affa>n, 1417 H./1997 M.), h. 131-139.

${ }^{27}$ Al-Bukha>ri>, op.cit., Juz. IV, h. 1651. Lihat juga: Abu> al-H\{usain Muslim ibn alHajja>j, al-Naisabu>ri>, al-Ja>mi’ al-S\}ah\{i>h\{li Muslim, Juz. III (Bairut: Da>r al-Jail, t.th.), h. 95. 
Nabawi ataukah mesjid Quba' lalu Rasulullah menjelaskannya bahwa mesjid yang dimaksud adalah mesjid Nabawi. ${ }^{28}$

Sedangkan contoh penafsiran Nabi terhadap ayat al-Qur'an setelah disalahpahami oleh sahabat antara lain adalah kesalahpahaman حتى يتبين لكم الخيط الأبيض من الخيط Adi> ibn Hati>m terhadap ayat dengan memaknainya secara tekstual yaitu benang putih dan hitam, lalu Rasulullah saw. mengatakan bahwa yang dimaksud dalam ayat tersebut bukan benang akan tetapi سواد الليل وبياض النهار (hitamnya malam dan putihnya siang). ${ }^{29}$

Sementara salah satu contoh penafsiran Nabi yang didahului oleh pertanyaan Nabi adalah pada saat Nabi membacakan surah alKaus|ar kemudian Nabi bertanya "Apakah kalian mengetahui apa itu al-kaus|ar?, kemudian menjelaskan maksud al-kaus|ar dengan mengatakan:

$$
\text { فإنه فر وعدنيه ربى عز وجل عليه خير كثير... }
$$

(al-Kaus|ar adalah sungai yang dijanjikan Allah kepadaku yang penuh dengan kebaikan....). ${ }^{30}$

\section{d. Tafsir Nabi dengan Pengamalan Ayat}

Salah satu cara Nabi menafsirkan ayat-ayat al-Qur'an adalah dengan mengamalkan ayat tersebut. Semisal pascaturunnya surah alNas\}r, Rasulullah banyak membaca سبحانك ربنا وبحمدك اللهم اغفر لي pada saat ruku' dan sujud. ${ }^{31}$

Semua cara atau metode penafsiran Nabi di atas, dapat dijadikan contoh penerapan kaidah yang terkait dengan tafsir Nabi yang harus didahulukan dari penafsiran-penafsiran yang lain.

\section{Kaidah Kedua}

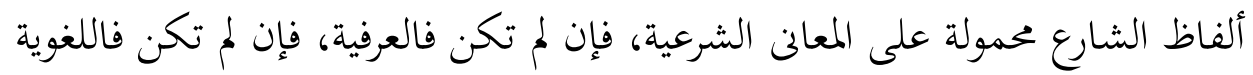

${ }^{28} \mathrm{Abu}>$ 'Isa $>\operatorname{Muh}\{\mathrm{ammad} \mathrm{ibn}$ 'Isa $>$ al-Turmuz $\mid \mathrm{i}>$, al-Ja $>m i$ ' al-S\}ah\{i>h\{Sunan alTurmuz $\mid i>$, Juz. II (Bairut: Da>r Ihya’ al-Tura>s| al-‘Arabi>, t.th.), h. 144.

${ }^{29}$ Al-Bukha>ri>, op.cit., Juz. II, 677 dan Muslim ibn al-Hajja>j, op.cit., Juz. III, h. 128.

${ }^{30}$ Muslim ibn al-Hajja>j, op.cit., Juz. II, h. 12.

${ }^{31}$ Al-Bukha>ri>, op.cit., Juz. IV, h. 1900. 


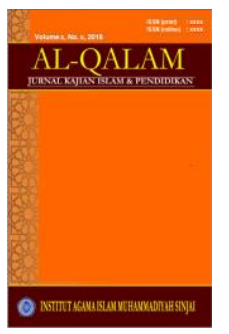

Artinya: "lafaz-lafaz syariat dilarikan kepada makna-makna syariatnya, jika tidak ditemukan makna syariatnya, maka diberi makna uruf (kebiasaan), jika tidak ada, maka dilarikan pada makna linguistiknya".

Sejalan dengan kaidah di atas adalah kaidah berikut:

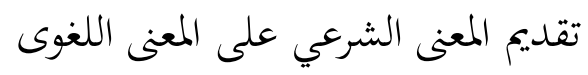

Artinya: "Mendahulukan makna syariat dari pada makna bahasa"32

Jika terdapat suatu kata memiliki dua makna atau lebih, salah satunya adalah makna bahasa, sedangkan makna yang lain adalah makna syariat, padahal kedua makna tersebut berbeda, maka makna yang didahulukan adalah makna syariat karena al-Qur'an diturunkan untuk menjelaskan syariat kecuali jika ada dalil yang menunjukkan makna lain.

Salah satu contoh kaidah tersebut adalah lafaz "shalat" dalam QS. al-Taubah: 84: ولا تصل على أحد منهم مات أبدا. Yang dimaksud dengan lafaz shalat dalam ayat tersebut adalah makna syariatnya yaitu shalat jenazah, meskipun terdapat makna lain dari shalat yaitu doa, yaitu bahasanya.

Contoh lain yang diberikan oleh Syaikh al-Isla $>m$ Ibnu Taimiyah adalah kata al-haj dalam ayat ولله على الناس حج البيت. kata al-haj tidak bisa dilarikan kepaka makna bahasanya yaitu semua tujuan dan maksud akan tetapi kata al-haj diartikan sebagai tujuan atau maksud tertentu tanpa harus merubah lafaznya. ${ }^{33}$

Jika tidak ditemukan penggunaan khusus terhadap lafaz dengan makna syariat tertentu, maka kata tersebut dikembalikan kepada makna 'uruf yang berlaku pada saat turunnya al-Qur'an, semisal kata $a l-d a>b b a h$ yang secara makna bahasa adalah semua hewan yang melata, akan tetapi makna 'uruf pada saat itu adalah hewan yang memiliki empat kaki. Hal itu didasarkan kepada kaidah "Suatu lafaz akan diturunkan berdasarkan 'uruf mayoritas penggunanya". ${ }^{34}$

Sedangkan lafaz yang maknanya tidak ditemukan dalam syariat dan 'uruf, maka makna lafaz tersebut dikembalikan kepada makna bahasanya.

Semua penjelasan tersebut berlaku, jika tidak ada indikasi atau dalil yang mengarahkan dari maknanya (syariat, uruf dan bahasa) kepada

${ }^{32}$ Fahd ibn 'Abd al-Rah\{man ibn Sulaima>n al-Ru>mi>, Buhu>s $\mid$ fi $>$ Us $\} u>l$ al-Tafsi>r wa Mana>hijih (Cet. IV; t.p. Maktabah al-Taubah, 1419 H.) h.143.

${ }^{33}$ Taqiy al-Di>n Ahmad ibn 'Abd al-H\{ali>m ibn Taimiyah, Majmu> ' al-Fata $>w a>$, Juz. VII (Cet. III; t.t.: Da>r al-Wafa>’, 1426 H./2005 M.), h. 299.

${ }^{34}$ Kha $>$ lid ibn 'Usma>n al-Sabt, op.cit., Juz. II, h. 152. 


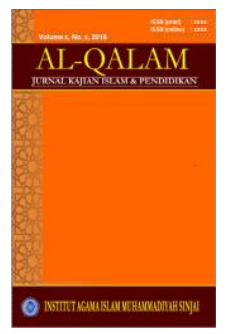

AL-QALAM

Jurnal Kajian Islam \& Pendidlikan

Volume 06 No 012014

ISSN (print) : 1858-4152

ISSN (online) : -

Homepage : $\underline{\text { http://journal.iaimsinjai.ac.id/index.php/al-qalam }}$

makna lain, ${ }^{35}$ semisal contoh yang terdapat indikasi pengalihan makna dari makna syariat kepada makna bahasa adalah kalimat وصل عليهم dalam surah al-Taubah: 103 dengan mengembalikan kepada makna bahasanya yaitu doa', karena ada indikator dari hadis lain yaitu:

كان رسول الله صلى الله عليه وسلم إذا أتاه قوم بصدقتهم قال "اللهم صل عليهم"

Artinya: "Rasulullah saw. jika datang kepadanya suatu kaum dengan membawa sedekah/zakatnya, dia berkata "Ya Allah, berilah mereka rahmat". ${ }^{36}$

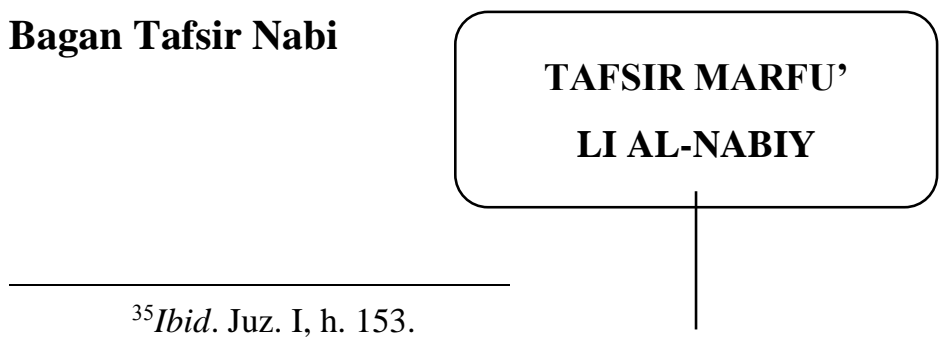

${ }^{36}$ Muslim ibn al-Hajja>j, op.cit., Juz. III, h. 121. 


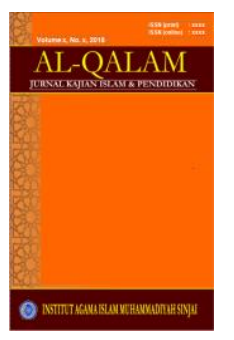

\section{AL-QALAM}

Jurnal Kajian Islam \& Pendidikan

Volume 06 No 012014

ISSN (print) : : 1858-4152

ISSN (online) : -

Homepage : $\underline{\text { http://journal.iaimsinjai.ac.id/index.php/al-qalam }}$

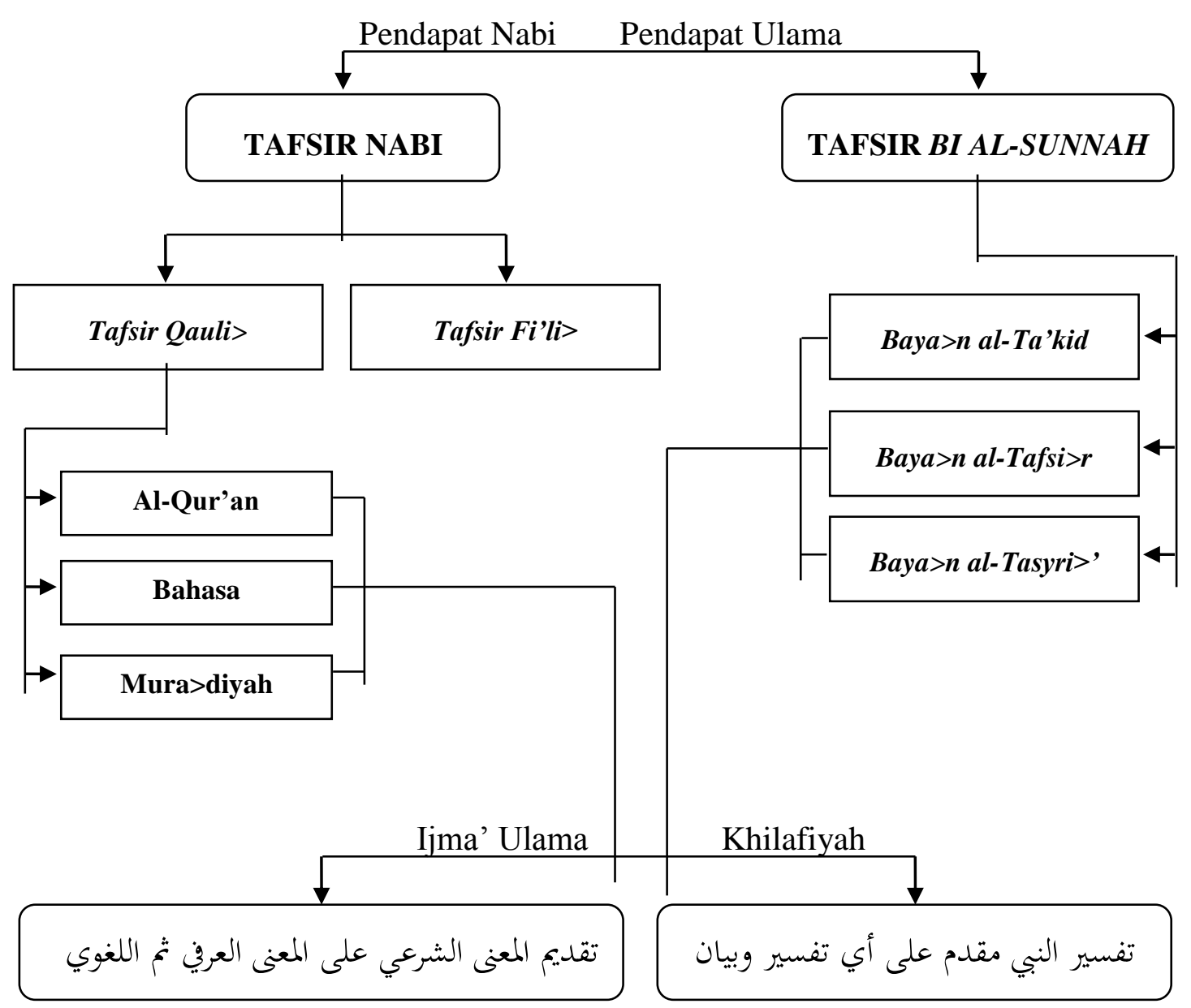




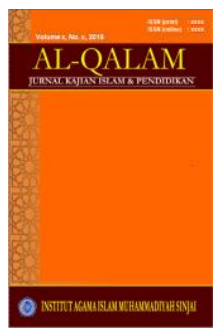

\section{Bentuk Kaidah Tafsir Sahabat dan Aplikasinya}

Sahabat merupakan generasi pertama yang menerima al-Qur'an, menyaksikan turunnya al-Qur'an secara berlahan-lahan, sekaligus sahabatlah orang pertama yang menerima penafsiran dari Rasulullah saw., bahkan para sahabat tidak meneruskan bacaan al-Qur'an lebih dari 10 ayat sebelum mengetahui dan memahami maksudnya dengan cara beriman, berilmu atau beramal. $^{37}$

Disamping sumber penafsiran sahabat langsung kepada al-Qur'an, Sunnah Rasulullah dan ahl al-Kita $>b$, ijtihad sahabat juga memiliki keistimewaan di mana mereka lebih mengetahui asal-usul peletakan bahasa Arab dan segala macam rahasianya, pengetahuan mereka terhadap adat-istiadat bangsa Arab, halihwal Yahudi dan Nasrani di Jazirah Arab di mana al-Qur'an diturunkan serta kemampuan dan wawasan keilmuan mereka yang begitu dalam dan luas. ${ }^{38}$

Berdasarkan beberapa argumen yang telah disebutkan, tafsir sahabat sudah sepantasnya didahulukan dari pada penafsiran orang-orang setelahnya, bahkan sebagiannya harus didahulukan, sebagaimana kaidah berikut:

$$
\text { قول الصحابي مقدم على غيره في التفسير وإن كان ظاهر السياق لا يدل عليه }
$$

Artinya: "Perkataan atau penafsiran sahabat didahulukan dari penafsiran para ulama setelahnya, meskipun zahir kalimatnya tidak menunjukkan hal itu" 39

Maksud dari kaidah tersebut adalah tafsir sahabat lebih didahulukan dari tafsir yang lain selain tafsir Nabi saw., meskipun makna redaksinya tidak menunjuk demikian, selama makna tersebut tidak bertetangan dengan tafsir Nabi saw. Jika tafsir sahabat bertentangan dengan tafsir Nabi saw, maka tafsir sahabat ditolak. ${ }^{40}$

Meskipun demikian, tafsir sahabat juga memiliki tingkkatan-tingkatan yang pada akhirnya akan berpengaruh kepada hukum penggunaan tafsir sahabat. Untuk lebih jelasnya, pemakalah akan menjelaskan hal tersebut sebagai berikut:

\section{Tafsir Sahabat yang Bebas dari Intervensi Apapun}

Tafsir sahabat yang tidak bisa diintervensi oleh rasio, maka hal itu dihukumi marfu' yang berkonsekwensi kewajiban merujuk kepada tafsir sahabat tersebut, seperti $a s b a>b$ al-nuzu>l, berita tentang alam gaib

37،Abd al-Rah\{ma>n ibn Na>s\}ir al-Sa'di>, al-Qawa>'id al-Hisa>n fi> Tafsi>r alQur'a>n (CD-ROM al-Maktabah al-Sya>milah), h. 3.

${ }^{38}$ Muh\{ammad al-Husain al-Z|ahabi>, op.cit., Juz. I, h.58.

${ }^{39}$ Kha $>$ lid ibn 'Us $\mid$ ma>n al-Sabt, op.cit., Juz. I, h. 186.

${ }^{40}$ Ibid. Juz. II, h. 186. 
sepanjang tidak diambil dari kisah-kisah israiliyat dan sejenisnya. Hal itu ditegaskan oleh al-Zarqa $>$ ni dan al-Zarkasyi $>$ dalam kitabnya. ${ }^{41}$

Salah contohnya, ayat نساؤكم حرث لكم فأتوا حرثكم أنى شئتم dimana Jabir ibn Abdillah mengatakan bahwa sebab turunya ayat tersebut adalah perkataan orang Yahudi bahwa suami yang mendatangi istrinya dari belakang, anaknya akan cacat. ${ }^{42}$

\section{Tafsir yang Merujuk kepada Bahasa}

Sahabat jika menafsirkan al-Qur'an dengan merujuk kepada bahasa yang ada para mereka, maka tidak ada keraguan untuk menjadikannya sebagai pegangan atau rujukan bahkan harus diterima sebagai sebuah tafsir yang benar karena mereka adalah ahl al-lisa $>n$ (pemilik bahasa Arab). ${ }^{43}$

Salah satu contohnya, ketika para sahabat menafsirkan kata القصر dalam QS. al-Mursala>t: 32 (إنها ترمي بشرر كالقصر) dengan mengatakan bahwa mereka membuat tiga kayu bakar dengan panjang \pm 3 siku lalu membangunnya untuk musim dingin, bangunan itulah yang disebut القصر.

\section{Tafsir yang Merujuk kepada Ahl al-Kita $>b$}

Sebagaimana diketahui bahwa riwayat israiliyat dapat dikelompokkan dalam tiga kelompok, yaitu:

a. Riwayat sah karena sesuai dengan al-Qur'an dan hadis Nabi.

b. Riwayat batil karena bertentangan dengan al-Qur'an dan hadis Nabi.

c. Riwayat yang tidak dibenarkan dan tidak didustakan. ${ }^{44}$

Salah satu contohnya adalah penjelasan tentang kisah Nabi Musa dalam ayat 26 dari surah al-Ma>idah: فيإها محرمة عليهم أربعين سنة يتيهون فئن Lengkapnya kisah tersebut terdapat dalam tafsir Ibn Jari>r. ${ }^{45}$

\section{Tafsir yang Menggunakan Ijtihad}

${ }^{41}$ al-Zarqa $>$ ni $>$, Mana $>$ hil al- 'Irfa $>n$ fi $>$ 'Ulu $>m$ al-Qur'a $>n$, op.cit., h. Juz. II, 37dan alZarkasyi>, al-Burha $>n f i>$ 'Ulu $>m$ al-Qur'a $>n$, op.cit., Juz. II, h. 157.

${ }^{42} \mathrm{Abu}>$ al-H $\}$ asan 'Ali $>\mathrm{ibn} \mathrm{Ah}\{\operatorname{mad}$ al-Wah $\{\mathrm{i}>\mathrm{di}>, A s b a>b$ Nuzu>l $a l-Q u r$ ' $a>n$ (Cet. I; Bairut: Da>r al-Kutub al-'Ilmiyah, 1411 H.), h. 77.

${ }^{43}$ al-Zarkasyi>, al-Burha $>n$ fi $>$ 'Ulu>m al-Qur'a>n, op.cit., Juz. II, h. 172.

${ }^{44} \mathrm{Kha}>$ lid ibn 'Us $\mid \mathrm{ma}>$ n al-Sabt, op.cit., Juz. I, h. 166.

${ }^{45} \mathrm{Abu}>\mathrm{Ja}$ 'far Muh\}ammad ibn Jari $>\mathrm{r}$ al-T $\}$ abari>, Ja $>m i$ ' al-Baya $>n$ fi $>$ Ta'wi $>l$ alQur'a>n, Juz. II (Dimasyq: Muassasah al-Risa>lah, 1420 H./2000 M.), h. 98. 


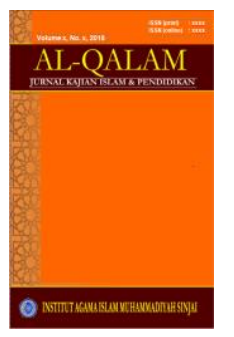

Penafsiran sahabat yang bersumber pada ijtihad, dapat dikelompokkan dalam tiga kelompok, yaitu:

\section{a. Tafsir Sahabat yang Hasil Ijtihadnya Sama}

Jika ijtihad sahabat terhadap satu kasus atau masalah kemudian hasilnya sama, maka dapat dipastikan ijtihad mereka dapat dijadikan hujjah karena hal itu masuk kategori ijma' sahabat. ${ }^{46}$

\section{b. Tafsir Sahabat yang Hasil Ijtihadnya Berbeda}

Jika terjadi perbedaan pendapat penafsiran sahabat terhadap sebuah kata al-Qur'an, kalimat atau ayat al-Qur'an, maka dilakukan altarji $>h\{$ kepada salah satu pendapat sahabat dengan tingkatan sebagai berikut:

1) Mendahulukan pendapat yang sesuai dengan al-Qur'an.

2) Mendahulukan pendapat yang sesuai dengan al-sunnah.

3) Mendahulukan pendapat sahabat yang paling benar cara kiyasnya. ${ }^{47}$

c. Tafsir Seorang Sahabat yang Ijtihadnya tidak Ditentang oleh Sahabat Lain

1) Ijtihad tersebut masyhur (terkenal)

Pendapat seorang sahabat yang sudah masyhur kemudian tidak ditentang oleh sahabat lain maka tidak disangsikan lagi bahwa pendapat tersebut dapat dijadikan sebagai hujjah, bahkan dianggap sebagai ijma' oleh mayoritas ulama, sebagaimana ungkapan Ibnu Taimiyah dalam kitab Majmu> ' al-Fata>wa>. ${ }^{48}$

2) Ijtihhad tersebut tidak masyhur (terkenal)

Sedangkan penafsiran sahabat yang tidak tersebar dan dikenal luas atau tidak jelas apakah tafsir sahabat tersebut dikenal luas atau tidak, maka dinggap hujjah oleh imam mazhab empat. ${ }^{49}$

${ }^{46}$ Kha $>$ lid ibn 'Us $\mid$ ma>n al-Sabt, op.cit., Juz. I, h. 182.

${ }^{47}$ Muh Jammad ibn Idri>s al-Sya>fi'i>, al-Risa>lah, (CD ROM al-Maktabah alSya>milah), h. 597. Namun menurut penulis, Tarji $>h\{$ dilakukan jika memang kualitas tafsir sahabat berbeda, akan tetapi jika kualitasnya sama, maka yang dilakukan adalah al-jam ' (memberlakukan keduanya atau memposisikan pada posisinya masing-masing. Jika metode aljam' tidak bisa diterapkan, maka al-tawwaquf atau al-maskut 'anhu adalah langkah terakhir dalam menanggapi perbedaan sahabat dalam menafsirkan al-Qur'an.

${ }^{48}$ Ibnu Taimiyah, op. cit., Juz. XX, h. 14.

${ }^{49}$ Kha $>$ lid ibn 'Us|ma>n al-Sabt, op.cit., Juz. I, h. 182. 

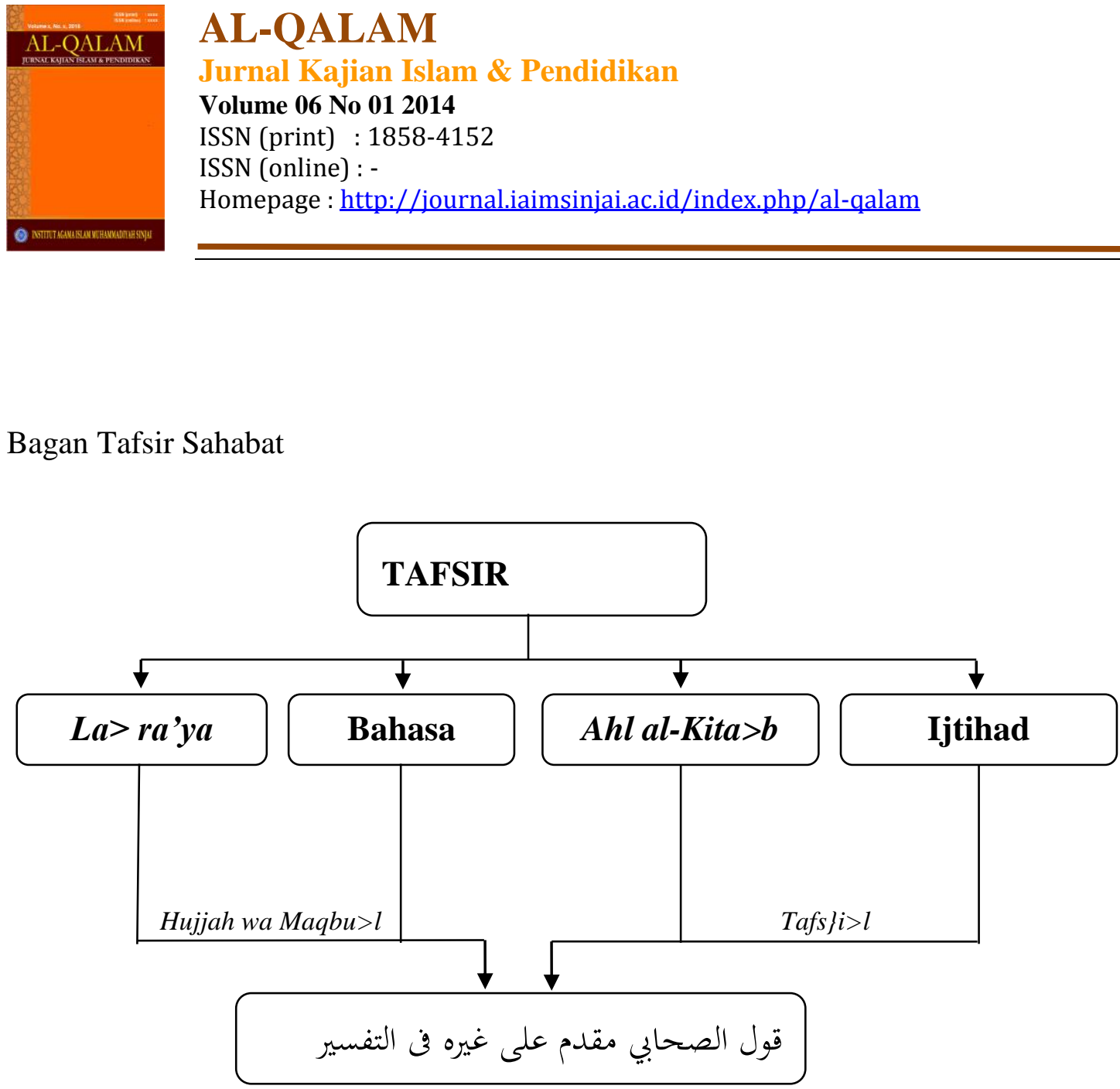

\section{PENUTUP}

\section{A. Kesimpulan}

Merujuk terhadap penjelasan-penjelasan di atas, dapat dibuat beberapa poin kesimpulan sebagai hasil pembahasan tentang kaidah tentang tafsir Nabi dan sahabat, sebagai berikut:

1. Kaidah tafsir adalah hukum-hukum universal yang digunakan dan dibutuhkan oleh para penafsir untuk sampai pada pengkajian makna-makna al-Qur'an dan mengetahui tata cara mendapatkan faedah-faedahnya. Sedangkan tafsir Nabi adalah penafsiran yang dilakukan oleh Rasulullah saw. dengan jelas, baik didahului oleh pertanyaan dan atau permintaan dari para sahabat atau tidak, akan tetapi langsung ditafsirkan sehingga ijtihad ulama dalam menafsirkan al-Qur'an dengan menggunakan hadis atau sunnah tidak masuk kategori tafsir Nabi akan tetapi disebut tafsi>r alQur'a $>n$ bi al-sunnah. Adapun tafsir sahabat adalah penafsiran yang dilakukan oleh para sahabat Nabi terhadap ayat-ayat al-Qur'an.

2. Bentuk kaidah tafsir Nabi dapat dikelompokkan dalam dua kelompok. Pertama: Penjelasan dan penafsiran Nabi terhadap lafaz-lafaz al-Qur'an didahulukan dari penjelasan apapun. Kedua: Mendahulukan makna syariat 


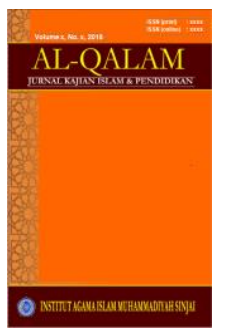

dari pada makna uruf dan atau bahasa. Sementara cara dan metode penafsiran Nabi dapat dibagi dalam empat bagian yaitu: 1) Tafsir Nabi dengan menggunakan ayat al-Qur'an, 2) Tafsir Nabi dengan pendekatan bahasa, 3) Tafsir Nabi dengan penjelasan mura>diyah dan 4) Tafsir Nabi dengan pengamalan ayat.

3. Sedangkan kaidah tafsir sahabat adalah "Perkataan atau penafsiran sahabat didahulukan dari penafsiran para ulama setelahnya, meskipun zahir kalimatnya tidak menunjukkan hal itu". Kaidah tersebut dapat diklasifikasi dalam empat bagian. Pertama: Tafsir sahabat yang bebas dari intervensi apapun. statusnya harus diterima dan menjadi hujjah. Kedua: Tafsir yang merujuk kepada bahasa juga menjadi hujjah dan diterima karena mereka adalah ahl lisa>n al-'Arab. Ketiga: Tafsir yang merujuk kepada ahl al$k i t a>b$ yang status kehujjahannya terbagi tiga yaitu diterima, ditolak dan tidak diterima dan tidak ditolak. Keempat: Tafsir yang menggunakan ijtihad juga dapat dibagi dalam tiga bagian lagi yaitu diterima sebagai sebuah ijma', dilakukan tarji>h\{ dan diterima sebagai hujjah oleh mayoritas ulama, khususnya maz $\mid a>$ hib al-Arba'.

\section{B. Implikasi}

Kaidah tafsir dapat diartikan sebagai pedoman dasar yang digunakan secara umum guna mendapatkan pemahaman atas petunjuk-petunjuk al-Qur'an. Oleh karena penafsiran merupakan suatu aktivitas yang senantiasa berkembang, sesuai dengan perkembangan sosial, ilmu pengetahuan dan bahasa, kaidah-kaidah penafsiran akan lebih tepat jika dilihat sebagai suatu prosedur kerja. Dengan pengertian ini, kaidah tersebut tidak mengikat kepada mufasir lain agar menggunakan prosedur kerja yang sama. Setiap mufasir berhak menggunakan prosedur yang berbeda asalkan memiliki kerangka metodologi yang dapat dipertanggungjawabkan.

Tafsir Nabi tetap diposisikan pada posisi utama dalam menafsirkan alQur'an dengan tetap memperhatikan hal-ihwal, peristiwa, kondisi, suasana dan masalah yang mengitari Nabi pada saat melakukan penafsiran terhadap al-Qur'an. Sedangkan tafsir sahabat dapat dipilah dan dipilih sesuai dengan kesesuaian dengan al-Qur'an dan sunnah. begitu juga kualitas status penafsirannya.

Tafsir Nabi dan sahabat harus tetap dilibatkan dalam penafsiran ayat-ayat al-Qur'an, bahkan dijadikan sebagai salah satu sumber penafsiran. kalaupun terjadi perbedaan penafsiran ulama kontemporer atau cendekiawan Islam dengan tafsir Nabi dan sahabat maka hal itu tidak harus divonis salah atau menyimpang akan tetapi harus memperhatikan latar belakang, metodologi, subtansi, subjek dan objek yang berbeda sehingga tidak mudah saling menyalahkan dan saling mengklaim kebenaran. 


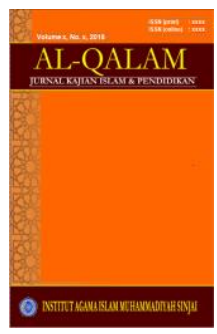

\section{DAFTAR PUSTAKA}

Agama, Departemen. al-Qur'an dan Terjemahnya. Bandung: Syaamil Cipta Media, 1426 H./2005 M.

Al-Alu>si>, Abu> al-Fad>1 Mah\{mu>d. Ru>h\{ al-Ma'a>ni> fi. Tafsi $>r$ alQur'a $>n$ al- 'Az\}i>m wa al-Sab'i al-Mas $\mid a>n i>$. Juz. I. Bairut: Da>r Ih\} ya> al-Tura $>$ s| al-'Arabi>, t.th.

Al-Bukha>ri>, Abu Abdillah Muhammad ibn Isma>'il. al-Ja>mi' al-S\}ah\{i>h li $a l-B u k h a>r i>$. Juz. VI. Cet. III; Bairut: Da>r Ibnu Kas|i>r, 1407 H./1987 M.

Al-Fayu >mi>, Ahmad ibn Muhammad ibn Ali. al-Mis $\} b a>h\}$ al-Muni>r fi> Gari $>b$ al-Syarh\} al-Kabi $>r$ li $a l-R a>f i$ ' $i>$. Juz. II. Bairut: al-Maktabah al-'Ilmiyah, t.th.

Al-Jurja $>$ ni $>$, Ali ibn Muhammad ibn Ali. $a l-T a ' r i>f a>t$. Cet. I; Bairut: Da>r alKita>b al-'Arabi>, $1405 \mathrm{H}$.

Al-Naisabu>ri>, Abu al-Husain Muslim ibn al-Hajja $>\mathrm{j}$, al-Ja $>m i$ al-S\}ah\{i>h\{li Muslim. Juz. III. Bairut: Da>r al-Jail, t.th.

Al-Qat\}t\}a>n, Manna'. Maba>his $\mid f i>$ 'Ulu>m al-Qur'a>n. Cet. XIX; Bairut: Muassah al-Risa>lah, 1406 H./1983 M.

Al-Ra>zi>, Abu Abdillah Muhammad ibn Umar Fakhruddin. Mafa>tih\} al-Gaib. Juz. XV. Bairut: Da>r al-Fikr, 1414 H./1992 M.।

$\mathrm{Al}-\mathrm{Ru}>\mathrm{mi}>$, Fahd ibn Abd Rahman ibn Sulaima>n. Buhu>s $\mid f i>U s\} u>l$ alTafsi>rwa Mana> hijih. Cet. IV; t.p. Maktabah al-Taubah, 1419 H.

Al-Sa'di >, Abd Rahman ibn Na>s\}ir. al-Qawa> 'id al-Hisa>n fi> Tafsi>r alQur'a>n. (CD-ROM al-Maktabah al-Sya>milah).

Al-Sabt, Khalid ibn Us|man. Qawa > 'id al-Tafsi>r, Jam'an wa Dira $>$ sah. Juz. I. Cet. I; al-Mamlakah al-'Arabiyah al-Sa'u $>$ diyah, Da $>$ r ibn 'Affa $>$ n, 1417 H./1997 M.

Al-Sya $>$ fi' $1>$, Muhammad ibn Idris. al-Risa>lah. (CD-ROM al-Maktabah alSya $>$ milah). 


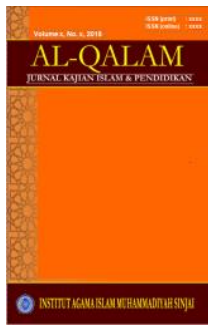

Al-T\{ayya $>$ r, Musa $>$ id ibn Sulaima $>n$ ibn Na $>$ s $\}$ ir. al-Tafsi $>r$ al-Lugawi $>$ li alQur'a $>n$ al-Kari>m. Cet.I; al-Riya $>$ d $\{:$ Da>r Ibn al-Jauzi $>1422$ H.

Al-T\}abari>, Abu Ja'far Muhammad ibn Jarir. Ja>mi' al-Baya $>n$ fi $>$ Ta'wi $>l$ alQur'a>n. Juz. II. Dimasyq: Muassasah al-Risa>lah, 1420 H./2000 M.

Al-Tu>nisi>, Muhammad al-T\{a>hir ibn Muhammad ibn Muhammad al-T\{a>hir ibn 'A $<$ syu $>$ r. al-Tahri $>r$ wa al-Tanwi $>r$. Juz. XIX. Tunis: al-Da $>$ r al$\mathrm{Tu}>$ nisiyah li al-Nasyr, $1984 \mathrm{H}$.

Al-Turmuz|i>, Abu 'Isa Muhammad ibn 'Isa. al-Ja>mi' al-S\}ah\{i>h\{ Sunan alTurmuz $\mid i>$. Juz. II. Bairut: Da $>$ r Ihya' al-Tura $>$ s $\mid$ al-'Arabi $>$, t.th.

Al-Wah $\{\mathrm{i}>\mathrm{di}>$, Abu al-Hasan Ali ibn Ahmad. Asba>b Nuzu>l al-Qur'a $>n$. Cet. I; Bairut: Da>r al-Kutub al-'Ilmiyah, $1411 \mathrm{H}$.

Al-Z|ahabi>, Muhammad Husain. al-Tafsi>r wa al-Mufassiru>n. (CD-ROM alMaktabah al-Sya>milah).

Al-Zarkasyi>, Abu Abdillah Muhammad ibn Baha>dir. al-Burha $>n$ fi $>$ 'Ulu>m $a l-Q u r^{\prime} a>n$, Juz. I. Bairut: Da>r al-Ma'rifah, $1391 \mathrm{H}$.

Al-Zarqa $>$ ni $>$, Muhammad Abd al-'Az $\}$ i $>$ m. Mana $>$ hil al-'Irfa $>n$ fi $>$ 'Ulu $>m$ alQur'a>n. Juz. I. Cet. I; Bairut: Da>r al-Fikr, 1996 M.

Asy-Syirbas \}i>, Ahmad. Sejarah tafsir al-Qur'an. Jakarta: Pustaka Firdaus, 2001 M.

Ibra>him, Muhammad Isma'i>1. al-Qur'a>n wa I'ja $>z u h$ al-'Ilmi>. Bairut: Da>r al-S|aqa>fah al-'Arabiyah, t.th.

Muslim, Mus\}t\}afa>. Maba>h\{is $\mid$ fi $>$ al-Tafsi $>r$ al-Maud $>u>$ 'i>. Cet.I; Damsyiq: Da>r al-Qalam, 1410 H./1989 M.

Shihab, M. Quraish. Tafsir al-Mishbah. Juz. VII. Jakarta: Lentera Hati, 2005 M.

Taimiyah, Taqiyuddin Ahmad ibn Abd Halim ibn. Majmu' al-Fata>wa>. Juz. VII. Cet. III; t.t.: Da>r al-Wafa>', 1426 H./2005 M.

Usman, H. Muchlis. Kaidah-kaidah Ushuliyah dan Fiqhiyah. Cet. IV; Jakarta: Raja Grafindo Persada, 2002 M.

Zakariya $>$, Abu> al-H\{usain Ah\}mad ibn Fa>ris ibn. Maqa>yi>s al-Lugah. Juz. IV. Bairut: Ittih \}a>d al-Kita>b al-'Arabi>, 1423 H./2002 M. 


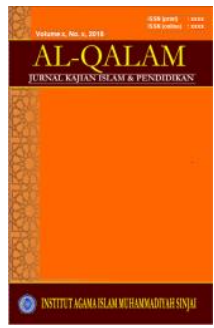

AL-QALAM

Jurnal Kajian Islam \& Pendidikan

Volume 06 No 012014

ISSN (print) : 1858-4152

ISSN (online) : -

Homepage : http://journal.iaimsinjai.ac.id/index.php/al-qalam 